TITLE:

\title{
Poecilostomatoid Copepods Parasitic in Bivalve Mollusks of Taiwan
}

\section{$\operatorname{AUTHOR}(S)$ :}

Lin, Ching-Long; Ho, Ju-Shey

\section{CITATION:}

Lin, Ching-Long ... [et al]. Poecilostomatoid Copepods Parasitic in Bivalve Mollusks of Taiwan. PUBLICATIONS OF THE SETO MARINE BIOLOGICAL LABORATORY 1999, 38(5-6): 201-218

ISSUE DATE:

1999-09-30

URL:

http://hdl.handle.net/2433/176288

RIGHT: 


\title{
Poecilostomatoid Copepods Parasitic in Bivalve Mollusks of Taiwan
}

\author{
Ching-Long Lin $^{11}$ and Ju-Shey $\mathrm{Ho}^{2)}$ \\ ${ }^{1)}$ Department of Aquaculture, National Chiayi Institute of Technology, \\ Chiayi 60083, Taiwan \\ ${ }^{2)}$ Department of Biological Sciences, California State University, \\ Long Beach, California 90840-3702, U.S.A.
}

\begin{abstract}
Three species of poecilostomatoid copepods parasitic in bivalve mollusks of Taiwan were described. They are: Ostrincola similis sp. nov. from the cultured oyster, Crassostrea gigas (Thunberg), and green mussel, Perna viridis (Linnaeus), attached to this species of oyster; Myicola formosanus sp. nov. from the circular clam, Cyclina sinensis (Gmelin); and Anthessius mytilicolus Reddiah, 1966 from the green mussels attached to the cultured $C$. gigas. This is the first report of parasitic copepods from the bivalve mollusks of Taiwan.
\end{abstract}

Key words: parasitic copepods, Poecilostomatoida, Myicolidae, Anthessiidae, bivalve mollusks, Taiwan

\section{Introduction}

Although the culture of bivalve mollusks has been in practice for more than a century in Taiwan, their parasitic copepods have not been studied in the past. However, knowing parasitic copepods can cause mass mortality of clams in culture (Ho, 1996), study of them has become more necessary.

In Taiwan, the oyster, Crassostrea gigas (Thunberg), and the hard clam, Meretrix lusoria (Roeding), are the two most widely cultured bivalve mollusks. Thus, they were purchased monthly from the market for examination of their copepod parasites. It is interesting to point out that while the oysters were found to harbor parasitic copepods, the hard clams were not. However, we consider this discrepancy is due to an artifact: while the oysters are cultured on the coastal inlets or bays, the hard clams are always cultured on the land in fish ponds, in which the salinity often rises up to $40 \%$ and prevents the occurrence of stenohaline poecilostomatoid copepods. Examination of the hard clams collected from the wild will be conducted in the future to check on this speculation.

During our one-year examination of oysters and hard clams for copepod parasites, the circular clams, Cyclina sinensi (Gmelin), were occasionally found on sale in the market; therefore, they were also included in our examination. Furthermore, the green mussel, Perna viridis (Linnaeus), were sometimes found attached to the cultured C. gigas, thus, they too were included in our survey.

\section{Materials and Methods}

The bivalves purchased from the market were brushed clean in running tap water to remove all debris on the shells. Then, the cleaned shells were opened one by one by cutting the adductor muscles and washed in a large beaker filled with seawater. After all shells of the same species were washed, the water in the beaker was decanted into a fine mesh plankton net. The debris collected in the net was then transferred into a petri dish filled with seawater and examined under a dissection microscope for copepods. The copepod parasites were picked with a pair of fine forceps and preserved in $70 \%$ alcohol.

In studying the morphology of the copepods, the alcoholized specimens were first soaked in lactic acid for a couple of hours, measured, and then dissected under a dissection microscope. The removed 
appendages were studied on a wooden slide following the method described by Humes \& Gooding (1964) under a compound microscope.

All drawings were made with the aid of a camera lucida and the measurements for the whole animal were taken from 20 randomly selected individuals. In the following, a full description is given of the female and for the male only those features exhibiting sexual dimorphism are mentioned. In the description of the new species, the habitus of the specimen is based on the holotype and paratype but the appendages are based on the dissected paratypes.

Table 1. Infection of Ostrincola similis in Crassostrea gigas cultured in Bu-Dai in Chiayi County, Taiwan.

\begin{tabular}{|c|c|c|c|}
\hline \multicolumn{2}{|c|}{$\begin{array}{l}\text { Collection } \\
\text { date }\end{array}$} & \multirow{2}{*}{$\begin{array}{c}\begin{array}{c}\text { Number of host } \\
\text { examined }\end{array} \\
252\end{array}$} & \multirow{2}{*}{ 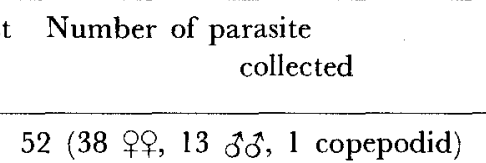 } \\
\hline 1997 & 0814 & & \\
\hline & 0908 & 482 & 36 (28 qq, $6 \delta^{\pi}, 2$ copepodids) \\
\hline & 1002 & 135 & $14(13$ +क, 1 б) \\
\hline & 1104 & 91 & 89 (70 o+, 12 $\delta \hat{\delta}, 7$ copepodids) \\
\hline & 1204 & 143 & 9 (6 ㅇ, 1 o, 2 copepodids $)$ \\
\hline \multirow[t]{7}{*}{1998} & 0112 & 161 & $6(5$ 우, 1 ठ \\
\hline & 0209 & 165 & 5 (3 \&O, 1 o, 1 copepodid $)$ \\
\hline & 0305 & 89 & $2(2$ 우 $)$ \\
\hline & 0416 & 169 & $2(29+)$ \\
\hline & 0504 & 111 & 0 \\
\hline & 0603 & 215 & 0 \\
\hline & 0701 & 202 & $3(3$ 아 $)$ \\
\hline Total & & 2,215 & $218(170$ 우, 35 कै $\widehat{O}, 13$ copepodids $)$ \\
\hline
\end{tabular}

Table 2. Infection of Ostrincola similis in Crassostrea gigas cultured in Wang-Gong in Zhan-Hwa County, Taiwan.

\begin{tabular}{|c|c|c|c|}
\hline \multicolumn{2}{|c|}{$\begin{array}{l}\text { Collection } \\
\text { date }\end{array}$} & $\begin{array}{l}\text { Number of host } \\
\text { examined }\end{array}$ & $\begin{array}{l}\text { Number of parasite } \\
\text { collected }\end{array}$ \\
\hline \multirow[t]{5}{*}{1997} & 0820 & 306 & $100(79$ \&९, 20 OA, 1 copepodid $)$ \\
\hline & 0918 & 294 & $84(75$ 우, 9 ठౌత) \\
\hline & 1016 & 325 & 45 (42 웅, 3 ठ人) \\
\hline & 1113 & 283 & 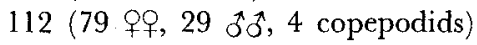 \\
\hline & 1210 & 259 & 54 (41 +q, 1230,1 copepodid) \\
\hline \multirow[t]{7}{*}{1998} & 0114 & 271 & 41 (34 우, 6 ô, 1 copepodid) \\
\hline & 0205 & 348 & 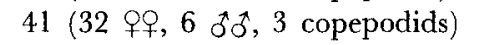 \\
\hline & 0303 & 309 & 29 (26 우, $2 \delta 3,1$ copepodid $)$ \\
\hline & 0414 & 311 & 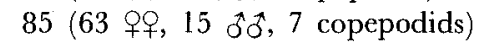 \\
\hline & 0519 & 266 & 79 (64 $9 q, 9$ J3, 6 copepodids) \\
\hline & 0616 & 298 & 58 (48 q̊, $6 \widehat{\delta 5}, 4$ copepodids) \\
\hline & 0713 & 257 & 97 (81 우, 14 \$ే, 2 copepodids) \\
\hline Total & & 3,527 & 825 (664 우, 131 ठోో 30 copepodids) \\
\hline
\end{tabular}




\section{Descriptions \\ Family Myicolidae Yamaguchi, 1936 \\ Ostrincola similis sp. nov.}

(Figs. 1-3)

Material examined

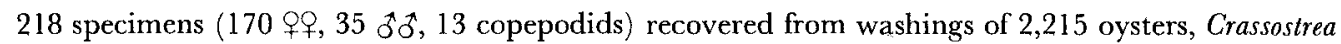
gigas (Thunberg), collected between August 1997 and July 1998 at Bu-Dai in Chiayi County, Taiwan (see Table 1 for collection dates and number of individuals recovered) and 825 specimens (644 우, $131 \delta \hat{\delta}, 30$ copepodids) recovered from washings of 3,527 oysters collected between August 1997 and July 1998 at Wang-Gong in Zhan-Hwa County, Taiwan (see Table 2 for collection dates and number of individuals recovered). 8 specimens $(7$ \&q, 1 ( ) recovered from washings of 36 green mussels, Perna viridis (Linnaeus) collected on September 1, 1998 at Bu-Dai in Chiayi County. Holotype (USNM 243655), allotype (USNM 243656) and 50 paratypes (USNM 243657, 25 $+q$ and $25 \delta^{*} \delta^{*}$ ) have been deposited in the National Museum of Natural History, Smithsoniam Institution, Washington, D. C., U.S.A.

Female

Body (Fig. 1A) 1,086 (963-1,221) $\mu \mathrm{m}$ long (excluding setae on caudal rami) and 276 (243-294) $\mu \mathrm{m}$ wide, with first pediger clearly separated from cephalosome. Urosome 5-segmented, genital double-somite (Fig. 1B) slightly longer than wide (1.156:1), bearing 4 transverse rows of spinules on ventral surface. Genital aperture (Fig. 1G) located dorsolaterally on widest part of somite and bearing 2 short setae representing remnants of leg 6. Abdomen (Fig. 1B) 3-segmented; first segment nearly as long as wide (1.04: 1) and bearing spinules along posteroventral margin; second segment longer than wide (1.19 : 1) but anal segment wider than long (1.29:1). Caudal ramus (Fig. 1D) slender, 10 times longer than wide, bearing 6 naked setae. Egg sac (Fig. 1A) uniseriate, with 2 to 5 eggs (mostly with 3 or 4). Antennule (Fig. 1E) 7-segmented, with formula of armature: 4, 14, $5,3,4+1$ aesthete, $2+1$ aesthete, and $7+1$ aesthete; all setae naked. Antenna (Fig. 1F) 3-segmented, with formula of armature: 1, 1 and $6+1$ claw. First segment (coxobasis) largest, with a row of spinules on anterior surface; second segment smallest; third segment about 6.5 times longer than wide, bearing a row of spinules on proximal outer surface. Labrum (Fig. 1G) broad, posteroventral edge concave with wide indentation; spinules on lateral edges forming densely packed patches and rows but scattered widely on ventral surface. Mandible (Fig. 1H) drawn out into a long, spinulated lash and with 3 setae bearing short, lateral spinules. Maxillule (Fig. 1I) a simple lobe armed with 4 unequal, simple setae. Maxilla (Fig. 2A) 2-segmented; first segment large, with patches of spinules on ventral surface; second segment small, with 2 spinulose setae and 1 small naked seta. Maxilliped absent.

Legs 1-4 (Figs. 2B, G, D, E) biramous with 3-segmented rami. Armature of legs as follows (Roman numerals indicating spines, Arabic numerals representing setae):

$\begin{array}{lllll}\text { Leg } & \text { Coxa } & \text { Basis } & \text { Exopod } & \text { Endopod } \\ 1 & 0-1 & 1-\mathrm{I} & \text { I-0; I-1; III,I,4 } & 0-1 ; 0-1 ; \mathrm{I}, 5 \\ 2 & 0-1 & 1-0 & \text { I-0; I-1; III,I,5 } & 0-1 ; 0-2 ; \text { III,3 } \\ 3 & 0-1 & 1-0 & \text { I-0; I-1; II,I,5 } & 0-1 ; 0-2 ; \text { IV,2 } \\ 4 & 0-1 & 1-0 & \text { I-0; I-1; II,I,5 } & 0-1 ; 0-2 ; \text { IV,1 }\end{array}$

Anterior surface of coxa on legs 1 and 2 with fine spinules. Basis of leg 1 with a posterior row of coarse spinules adjacent to inner spine in addition to scattered fine spinules. Outer surface 


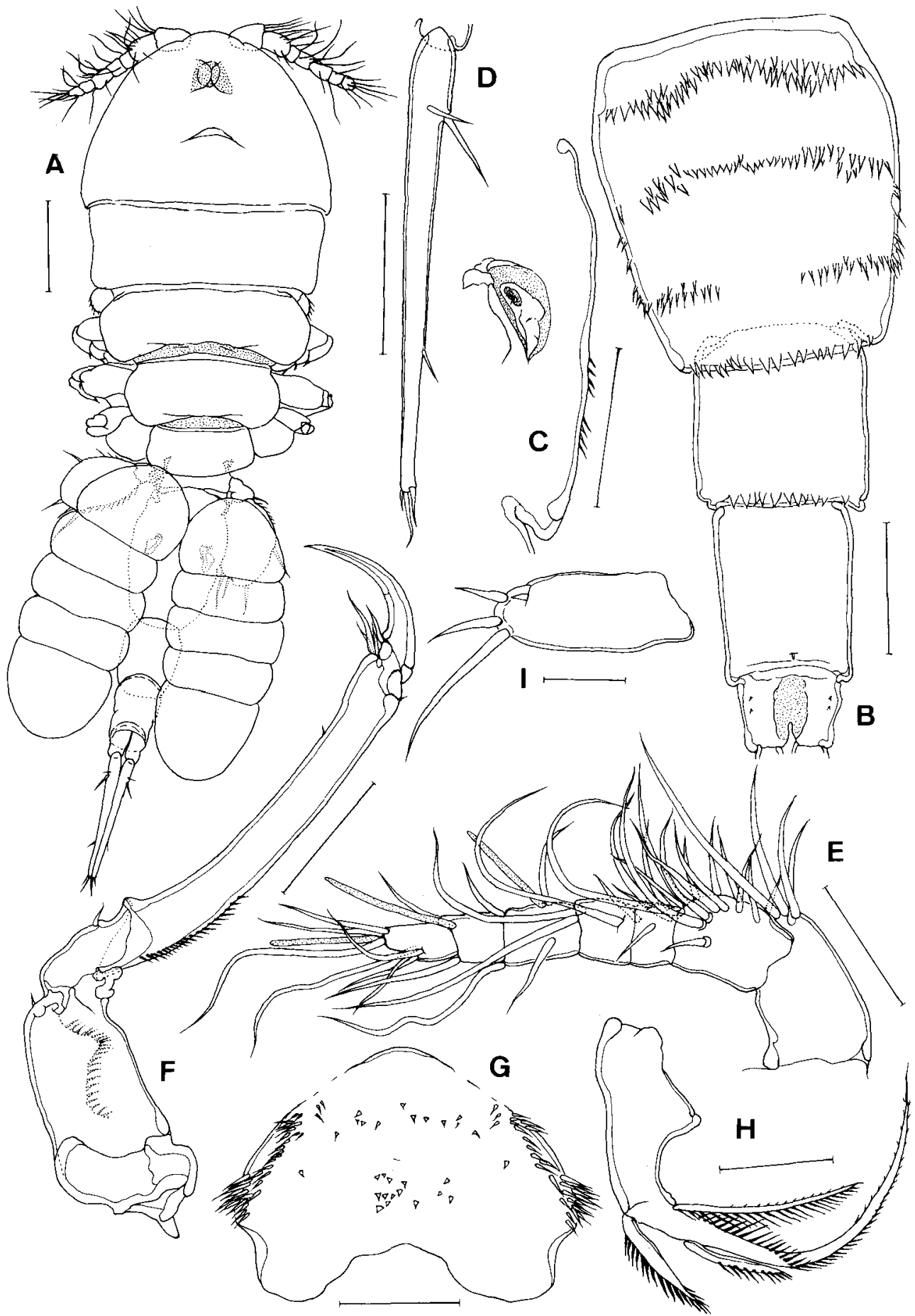

Fig. 1. Ostrincola similis sp. nov., female: A. habitus, dorsal; B. genital-double somites and abdomen, ventral; C. egg sac attachment area; D. caudal ramus; E. antennule; F. antenna; G. labrum; H. mandible; I. maxillule. Scale bars: $0.1 \mathrm{~mm}$ in A; $0.05 \mathrm{~mm}$ in B, C, D; $0.04 \mathrm{~mm}$ in E, F; $0.03 \mathrm{~mm}$ in $\mathrm{G} ; 0.02 \mathrm{~mm}$ in $\mathrm{H} ; 0.01 \mathrm{~mm}$ in $\mathrm{I}$. 


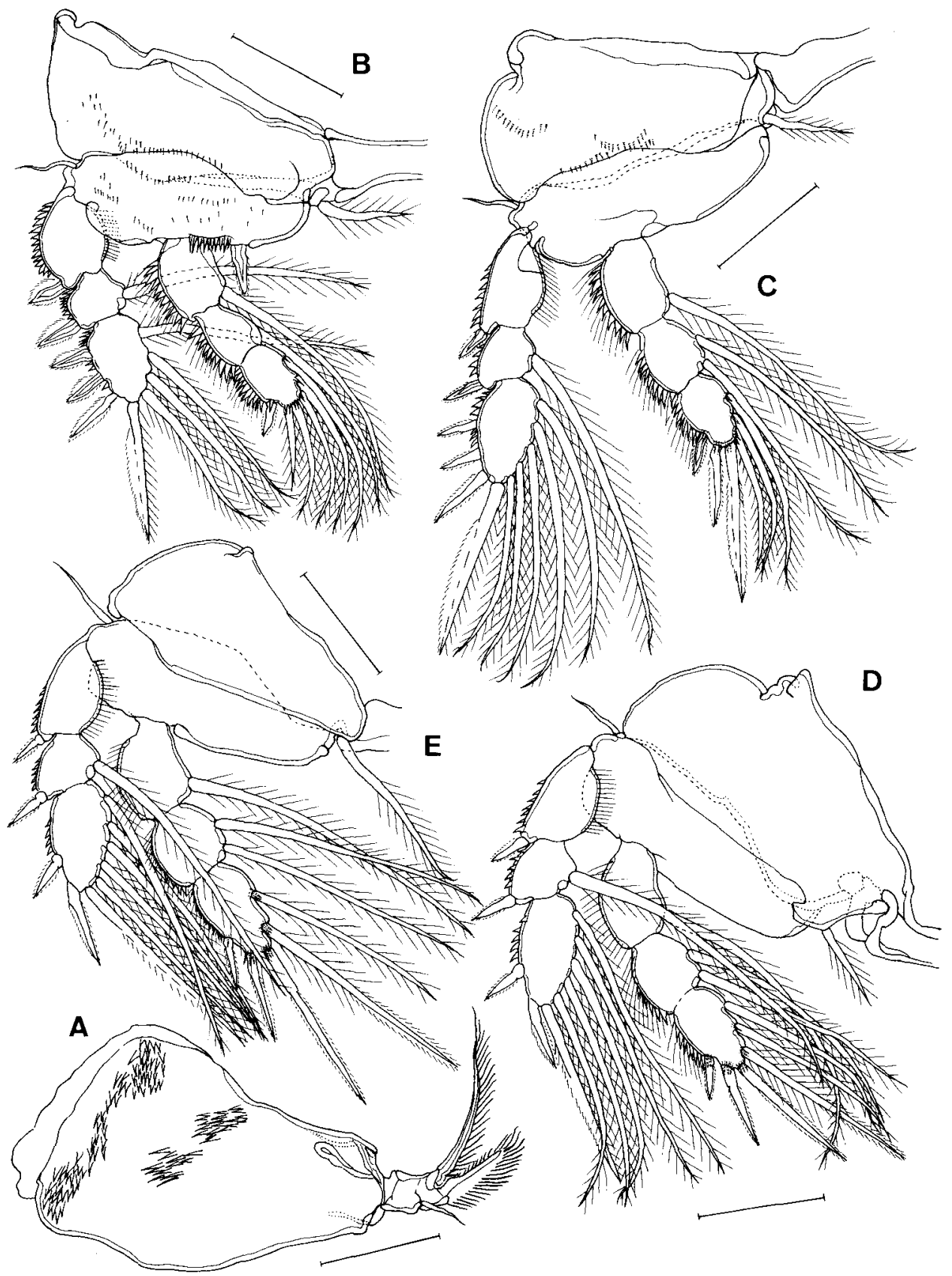

Fig. 2. Ostrincola similis sp. nov., female: A. maxilla; B. leg 1; C. leg 2; D. leg 3; E. leg 4. Scale bars: $0.03 \mathrm{~mm}$ in $\mathrm{A} ; 0.04 \mathrm{~mm}$ in $\mathrm{B}, \mathrm{C}, \mathrm{D}, \mathrm{E}$.

of both rami on all legs bearing rows of spinules. Row of hairs in addition to spinules on all endopodal segments except for basal segments on legs 3 and 4 .

Leg 5 (Fig. 3A) 2-segmented, with 1 outer seta on proximal segment and 2 setae and 


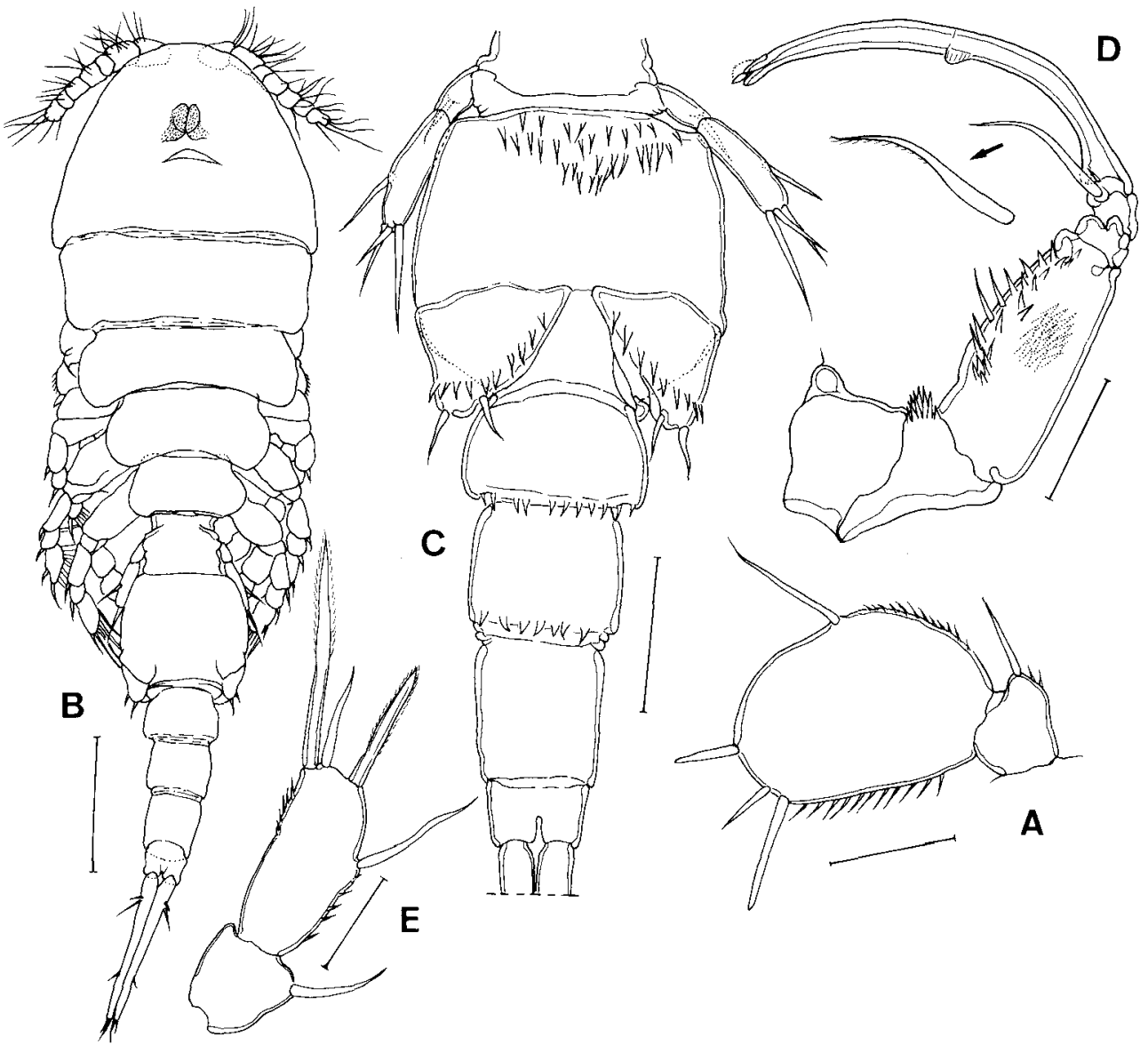

Fig. 3. Osirincola similis sp. nov. Female: A. leg 5. Male: B. habitus, dorsal; C. ursome, ventral; D. maxilliped; E. leg 5. Scale bars: $0.04 \mathrm{~mm}$ in A; $0.1 \mathrm{~mm}$ in B; $0.05 \mathrm{~mm}$ in $\mathrm{C} ; 0.03 \mathrm{~mm}$ in $\mathrm{D} ; 0.02 \mathrm{~mm}$ in $\mathrm{E}$.

2 blunt-tipped, spine-like setae on distal segment. Distal segment oval, about 1.5 times longer than wide; with row of spinules on both lateral and medial edges proximal to insertations of setae. Leg 6 represented by 2 minute setae located in egg sac attachment area (Fig.1C).

Male

Body (Fig. 3B) 836 (662-954) $\mu \mathrm{m}$ long (not including setae on caudal rami) and 209 (193-242) $\mu \mathrm{m}$ wide.Urosome 6-segmented; ventral surface of genital somite with a patch of spinules on anteroventral surface and oblique row of spinules on each ventrolateral, genital lobe; 2 setae on genital lobe representing leg 6 . First 2 abdominal somites with posteroventral row of spinules. Caudal ramus about 11.2 times longer than wide. Antennule as in female, except for addition of 1 aesthete on second segment and 2 aesthetes on fourth segment. Maxilliped (Fig. 3D) 4-segmented; first 2 segments with denticles; formula of armature: $0,2,0$ and 2 . Terminal segment drawn out into a curved claw, with a small hyaline lamella at midway on medial edge. Leg 5 (Fig. 3E) slender than female; distal 
Table 3. Morphological differences between Ostrincola japonica and $O$. similis.

\begin{tabular}{|c|c|c|}
\hline Characters & Osirincola japonica & Ostrincola similis \\
\hline \multicolumn{3}{|l|}{ Female: } \\
\hline Antennular $2^{\text {nd }} \& 3^{\text {rd }}$ segments with & $15 \& 6$ setae & $14 \& 5$ setae \\
\hline Antennal $3^{\text {rd }}$ segment & short $(\mathrm{L} / \mathrm{W}=4.3: 1)$ & long $(\mathrm{L} / \mathrm{W}=6.5: 1)$ \\
\hline Proximal 2 setae on caudal ramus & set far apart & closely set \\
\hline \multicolumn{3}{|l|}{ Male: } \\
\hline Medial spine on leg 5 & shorter than ramus $(0.51)$ & longer than ramus $(1.18)$ \\
\hline Leg 5 distal segment & long $(\mathrm{L} / \mathrm{W}=2.90: 1)$ & short $(\mathbf{L} / \mathrm{W}=2.11: 1)$ \\
\hline
\end{tabular}

segment about 2.03 times longer than wide, with spines much heavier than those in female. Leg 6 (Fig. 3C) represented by posteroventral flap on genital somite bearing row of coarse spinules and 2 small setae.

Etymology

The specific name, similis (= "like, resembling" in Latin), alludes to the great resemblance between Ostrincola japonica and the present species.

\section{Remarks}

It is not surprising to find out that in following the "Key to the species of Ostrincola" constructed by Ho \& Yoosukh (1994), the present new species of Ostrincola from Taiwan was identified with $O$. japonica Tanaka, 1961, which is known from both Japan and Korea. However, a close comparison of the details of the appendages revealed that the Ostrincola from Taiwan is a different species. Since the original description of $O$. japonica made by Tanaka (1961) is inadequate, lacking fine features which are significant in species recognition, we compared the specimens from Taiwan with the redescription made by Ho \& Kim (1991). The major differences are summarized in Table 3. Besides, the female leg 5 in $O$. similis is in general more weakly armed than in $O$. japonica.

Having an armature of $I, 5$ on the third segment of leg 1, a long caudal ramus (greater than 6:1 in $\mathrm{L} / \mathrm{W}$ ratio), a long third segment of antenna (greater than $6: 1 \mathrm{in} \mathrm{L} / \mathrm{W}$ ratio) and a long leg 5 (greater than 1.6:1 in $\mathrm{L} / \mathrm{W}$ ratio), the new species also shows close affinity with $O$. falcatus Humes, 1984 and $O$. patagonianus Humes, 1988. Nevertheless, it can be distinguished from the former by having a much longer caudal ramus (10.0:1 vs 6.7:1) and bearing spinules on outer margin of leg 5 in the female, and from the latter by carrying shorter setae (at most 1/5 of ramus length) at the tip of the caudal ramus and with the first two abdominal somites being longer than wide in the female.

\section{Myicola formosanus sp. nov.}

(Figs. 4-6)

Material examined

All specimens were recovered from the washings of the circular clams, Cyclina sinensis

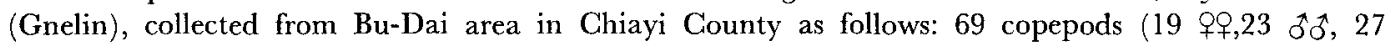
copepodids) from washings of 148 clams purchased on 18 November 1997; 34 copepods (11 우우, 6 $\hat{\delta} \hat{\sigma}, 18$ copepodids) from washings of 136 clams purchased on 4 July 1998; 22 copepods (11 $\delta \hat{\delta}, 3$ ơ⿱乛⿻ 8 copepodids) from washings of 104 clams purchased on 5 July 1998; 263 copepods (87 우우, 98 


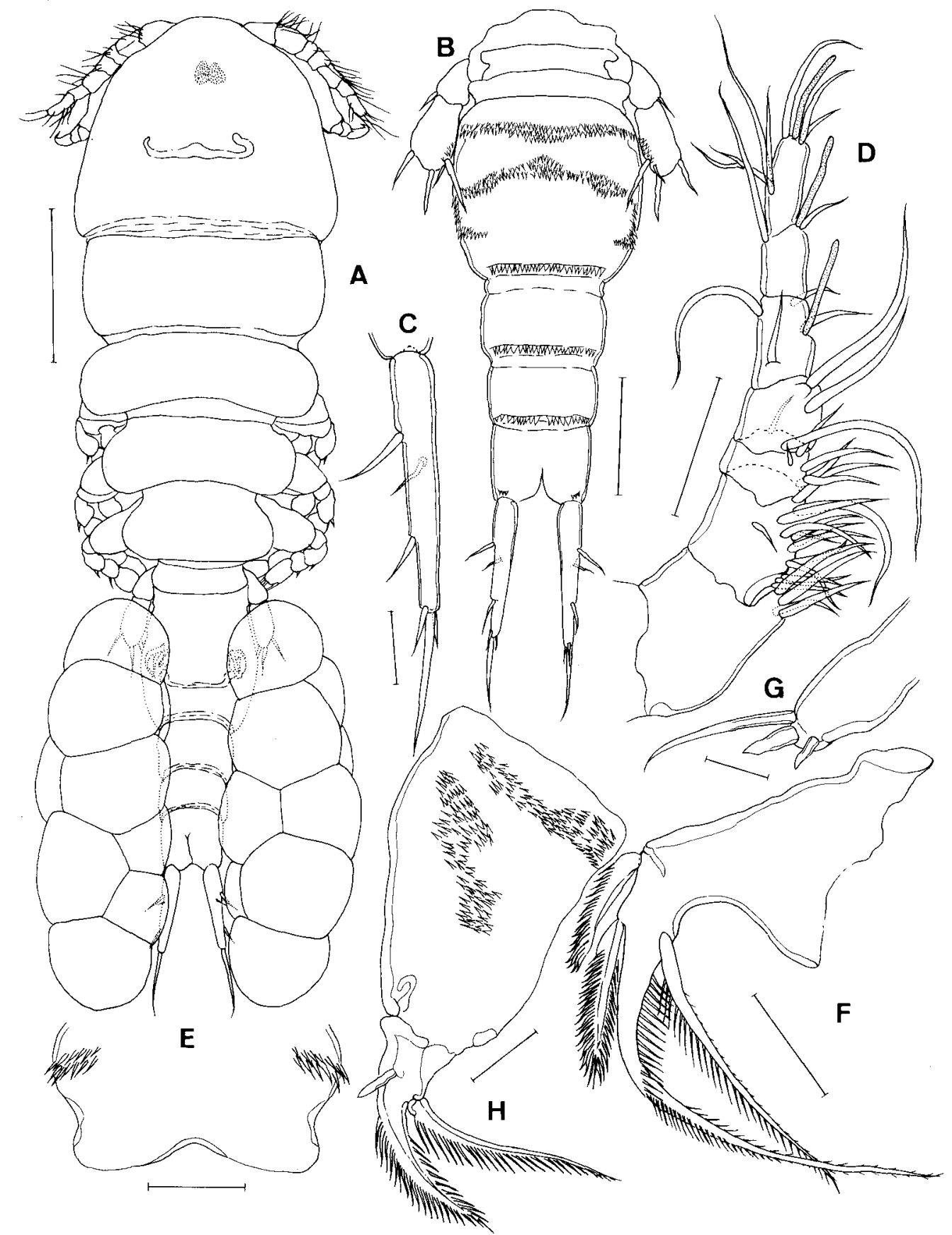

Fig. 4. Myicola formosanus sp. nov., female: A. habitus, dorsal; B. urosome, ventral; C. caudal ramus; D. antennule; E. labrum; F. mandible; G. maxillule; H. maxilla. Scale bars: $0.2 \mathrm{~mm}$ in $A ; 0.1 \mathrm{~mm}$ in $\mathrm{B} ; 0.03 \mathrm{~mm}$ in $\mathrm{C}$; $0.05 \mathrm{~mm}$ in $\mathrm{D}, \mathrm{E} ; 0.02 \mathrm{~mm}$ in $\mathrm{F}, \mathrm{H} ; 0.01 \mathrm{~mm}$ in $\mathrm{G}$.

$\widehat{0} \sigma^{7}, 78$ copepodids) from washings of 167 clams purchased on 19 July 1998 . Holotype (USNM 243658), allotype (USNM 243659) and 20 paratypes (USNM 243660, 10 क⿻ and 10 उో) have been deposited in the National Museum of Natural History, Smithsonian Institution, Washington, D.C., 


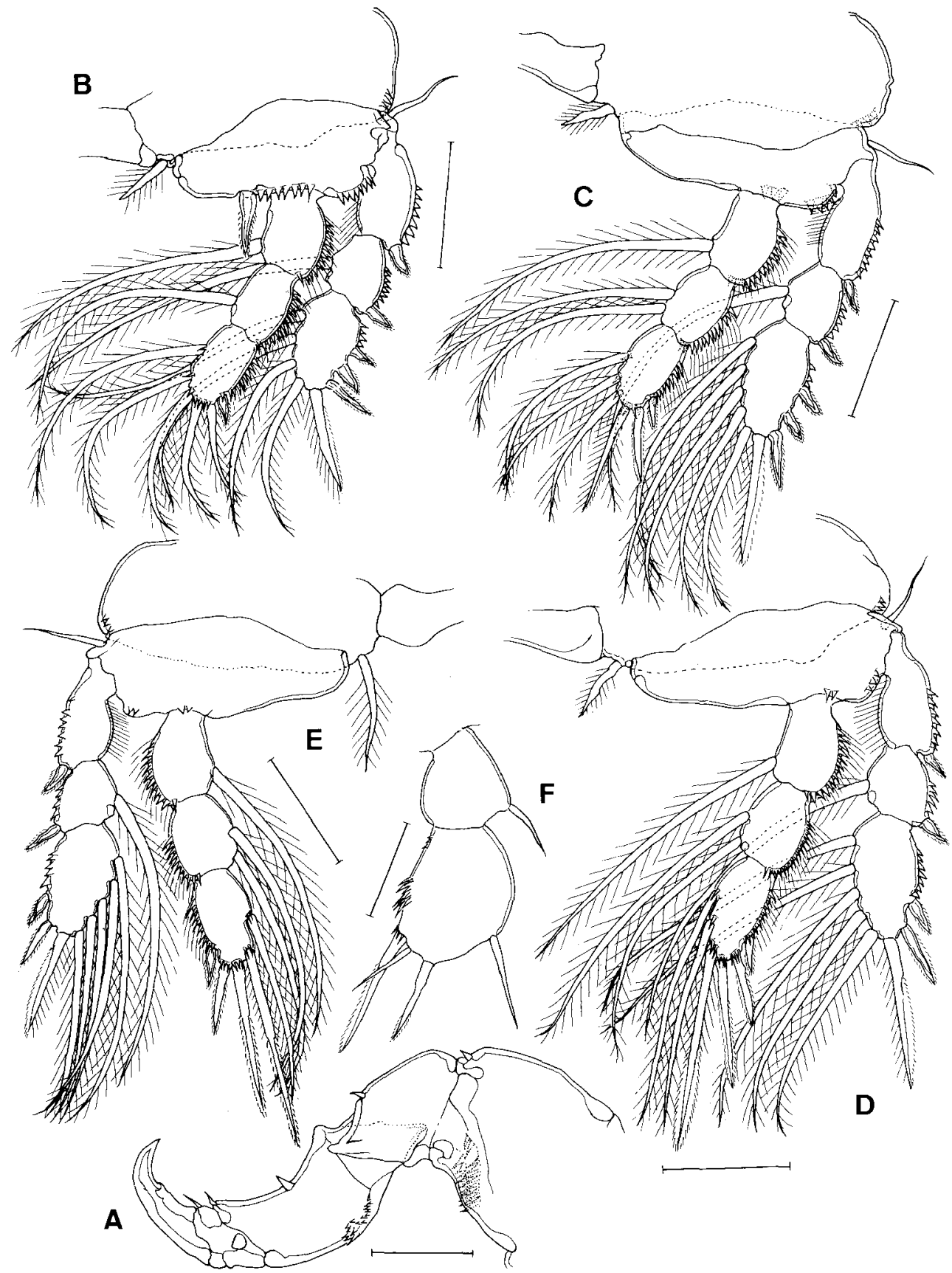

Fig. 5. Myicola formosanus sp. nov., female: A. antenna; B. leg 1; C. leg 2; D. leg 3; E. leg 4; F. leg 5. Scale bars: $0.04 \mathrm{~mm}$ in A, F; $0.05 \mathrm{~mm}$ in B,C,D,E.

U.S.A. Following description is based on the paratrypes.

\section{Female}

Body (Fig. 4A) 1,182 (874-1,423) $\mu \mathrm{m}$ long (excluding setae on caudal rami) and 334 


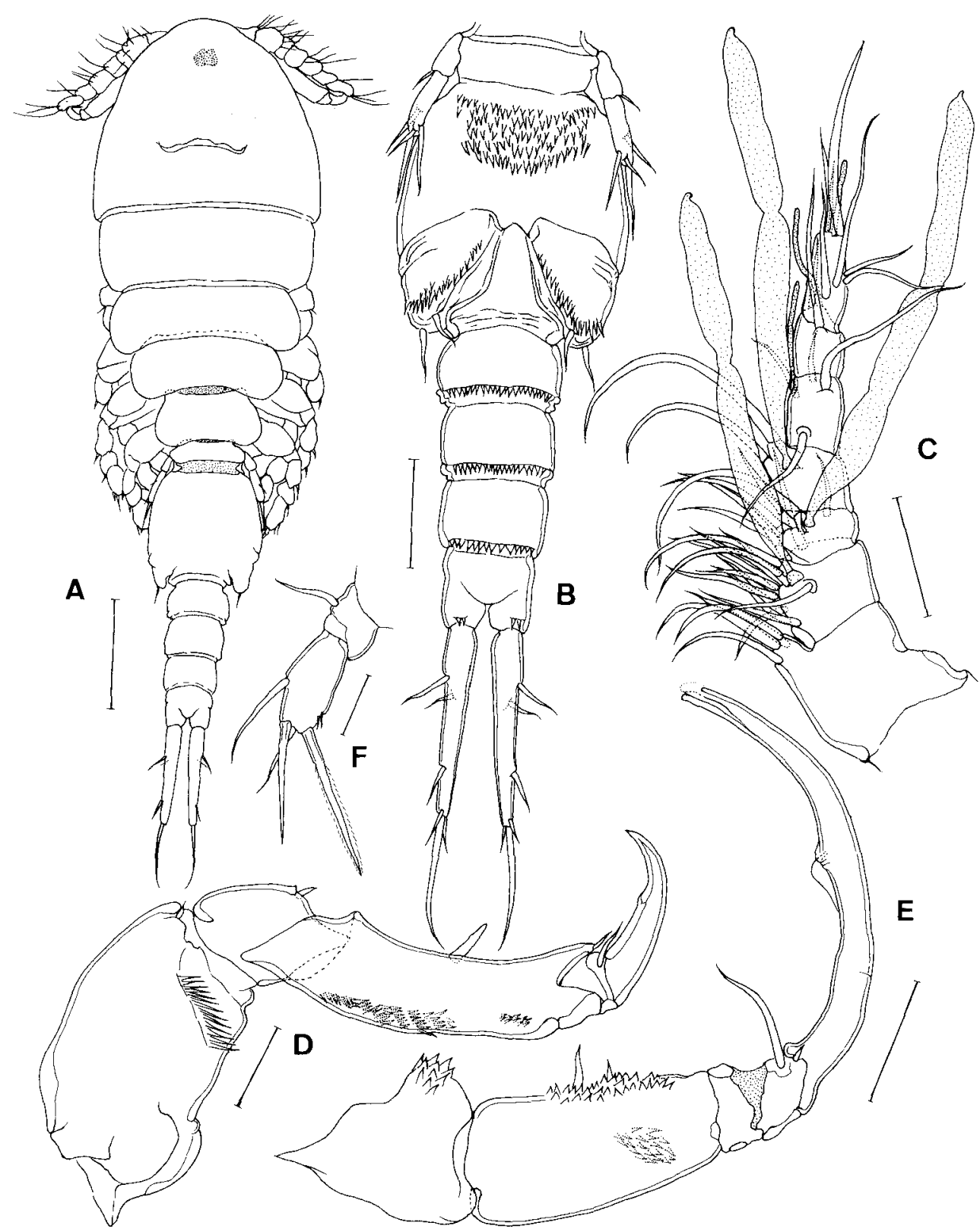

Fig. 6. Myicola formosanus sp. nov., male: A. habitus, dorsal; B. urosome, ventral; C. antennule; D. antenna; E. maxilliped; F. leg 5. Scale bars: $0.1 \mathrm{~mm}$ in A; $0.05 \mathrm{~mm}$ in B; $0.03 \mathrm{~mm}$ in C, E; $0.02 \mathrm{~mm}$ in D,F.

(283-371) $\mu \mathrm{m}$ wide, with first pediger clearly separated from cephalosome. Urosome (Fig. 4B) 5-segmented, genital double-somite bearing 2 complete and 2 partial transverse rows of spinules on ventral surface. Abdomen (Fig. 4B) 3-segmented; width of somites gradually narrowed from anterior to posterior; proximal 2 somites with a complete, posteroventral transverse row of spinules and anal somite with only a few spinules in the same area. Caudal ramus (Fig. 4C) 4.92 times longer than wide, bearing 6 naked setae. Egg sac (Fig. 4A) multiseriate, containing about 10-12 eggs. 
Antennule (Fig. 4D) 7-segmented, with formula of armature: 4, 15, 5, 3, 4+1 aesthete, $2+1$ aesthete, and $7+1$ aesthete; all setae naked. Antenna (Fig. 5A) 3-segmented. First segment (= coxobasis) largest, armed distally with transverse rows of spinules and 1 small inner distal seta; second segment (= first endopodal segment) with 1 small inner seta; third segment 2.29 times longer than wide, armed with 1 median seta on inner surface, 2 distal setae, and a number of spinules on outer surface. Terminal claw strong, rather short and acutely pointed. Labrum (Fig. 4E) broad, posteroventral edge concave with wide but shallow indentation; 2 rows of spinules on lateral, protruded area. Mandible (Fig. 4F) constructed as in $O$. similis. Maxillule (Fig. 4G) a simple lobe tipped with 3 unequal setae. Maxilla (Fig. 4H) 2-segmented; first segment large, with patches of spinules on ventral surface; second segment small, with 2 spinulose setae and 1 small naked seta. Maxilliped absent.

Legs 1-4 (Figs. 5B, C, D, E) biramous with 3-segmented rami. Armature of legs as in previous species. Outer-distal surface of coxa and posterior margin of basis on legs 1-4 with denticles. Outer surface of both rami on all legs also bearing denticles. Row of hairs in addition to denticles on all outer surface of endopodal segments.

Leg 5 (Fig. 5F) 2-segmented, with 1 outer seta on proximal segment and 2 setae and 2 spines on distal segment. Distal segment with straight medial margin and convex lateral margin, about 1.34 times longer than wide, and bearing spinules on medial surface and base of inner spine. Leg 6 represented by 2 small setae located in egg sac attachment area.

Male

Body (Fig. 6A) 854 (633-962) $\mu \mathrm{m}$ long (not including setae on caudal rami) and 213 (174-233) $\mu \mathrm{m}$ wide. Urosome (Fig. 6B) 6-segmented; ventral surface of genital somite bearing a large patch of spinules on anteroventral surface and oblique row of spinules on each ventrolateral, genital lobe. First 3 abdominal somites with posteroventral row of spinules, but only a few spinules on same area of anal somite. Caudal ramus about 6.25 times longer than wide. Antennule (Fig. 6G) 7-segmented, with formula of armature as in female except for segments 2, 3 and 4 which are: $14+1$ aesthete, $6+1$ aesthete and $2+1$ aesthete, respectively. Antenna 3-segmented; with formula of armature as in female but different in arrangement of spinules; $3^{\text {rd }}$ segment longer, about 3.55 times longer than wide. Maxilliped (Fig. 6E) 4-segmented; first 2 segments with denticles; formula of armature: $0,2,0$ and 2. Terminal segment drawn out into a curved claw, with a small hyaline lamella and denticles at midway on medial edge. Leg 5 (Fig. 6F) more slender than female; distal segment about 1.95 times longer than wide, with both terminal spines distinctly longer than segment.

\section{Etymology}

The specific name, formosanus, is a Latinized word of "Formosa" which is the name of Taiwan in Portuguese commonly used in the western history before the $20^{\text {th }}$ century.

\section{Remarks}

Three species of Myicola are known so far: M. metisiensis Wright, 1885 from the Atlantic coast of North America (Humes, 1986), M. ostreae Hoshina \& Sugiura, 1953 from Japan and Korea (Ho \& Kim, 1991), and M. intumidus Kim, 1997 from Korea (Kim, 1997). Having a combination of (1) an uniflated prosome, (2) a pair of egg sacs with a few rows of eggs, and (3) a large aesthete on the second, third and fourth antennular segments of the male, the new species of Myicola from Taiwan seems to be more closely related to $M$. intumidus than to either one of the remaining two species.However, a close comparison with Kim's 
Table 4. Morphological differences between Myicola intumidus and M. formosanus.

\begin{tabular}{|c|c|c|}
\hline Characters & Myicola intumidus & Myicola formosanus \\
\hline Urosome in female & short, 0.29 of body length & long, 0.42 of body length \\
\hline Number of eggs in egg sac & about 30 & no more than 12 \\
\hline Median spine on leg 5 in female & distinctly shorter than ramus & about as long as ramus \\
\hline Median spine on leg 5 in male & shorter than ramus & distinctly longer than ramus \\
\hline Caudal ramus in female & 3.91 longer than wide & 4.92 longer than wide \\
\hline
\end{tabular}

(1997) original description revealed that they are not conspecific. Some major species distinctions between $M$. intumidus and the new species are summarized as in Table 4. Copepods of the genus Myicola are distinguished from those of Ostrincola chiefly by their ovigerous females, with the former bearing a pair of egg sacs with multiseriate eggs and the latter, a pair of uniseriate egg sacs (Ho \& Kim, 1992). Thus, it is rather significant when Kim (1997) stated that species of Ostrincola tend to have slender caudal ramus (with the ratio of length to width greater than 5.25 in adult female) than those of Myicola, in which the most slender one is 4.95 as seen in $M$. ostreae. Furthermore, both Humes (1986) and Kim (1997) claimed that the body size of Myicola is generally larger than that of Ostrincola, even the smallest measures $1.65 \mathrm{~mm}$ in length as seen in $M$. ostreae.

However, with the discovery of $M$. formosanus, Kim's (1997) conclusion needs to be reconsidered. The new species from Taiwan is not only smaller $(1.18 \mathrm{~mm}$ in length) than the largest Ostrincola $(1.32 \mathrm{~mm}$ seen in $O$. portonoviensis) but also has its caudal ramus $(4.92$ in length to width) as thin as those in the Ostrincola. Thus, the distinction between Myicola and Ostrincola is again left with only the number of the rows of eggs in the egg sac as claimed by Ho \& Kim (1992).

\section{Family Anthessiidae Humes, 1986 Anthessius mytilicolus Reddiah, 1966}

(Figs. 7-9)

Material examined

All specimens were recovered from the washings of green mussels, Perna viridis (Linnacus), attached

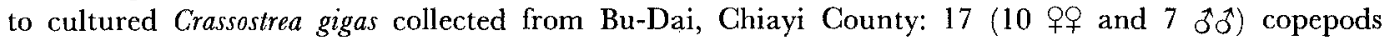
from washings of $5 P$. viridis collected on July 28, 1998 and 112 (40 $+9,62$ ô, 10 copepodids) copepods from washings of $36 P$. viridis collected on September 1, 1998.

Female

Body (Fig. 7A) measuring 1,734 (1,641-1,824) $\mu \mathrm{m}$ long (excluding setae on caudal rami) and 633 (603-642) $\mu \mathrm{m}$ wide, with first pediger clearly separated from cephalosome. Urosome 5-segmented, fifth pediger carrying a plumose outer seta on dorsal surface, genital double-somite (Fig. 7B) constricted anteriorly but dimension being as wide as long. Genital aperture (Fig. 7G) located dorsolaterally and posterior to widest part of somite, bearing 2 short setae representing remnants of leg 6. Abdomen (Fig. 7B) 3-segmented; first and second segments nearly equally in length and shorter than anal segment, which is distinctly longer than wide (1.29:1) and bearing rows of spinules on posteroventral margin. Caudal ramus (Fig. 7D) slender, 5.5 times longer than wide; bearing usual 6 setae. Egg sac (Fig. 7A) multiseriate.

Rostrum (Fig. 7E) not well defined. Antennule (Fig. 7F) 7-segmented, with formula 


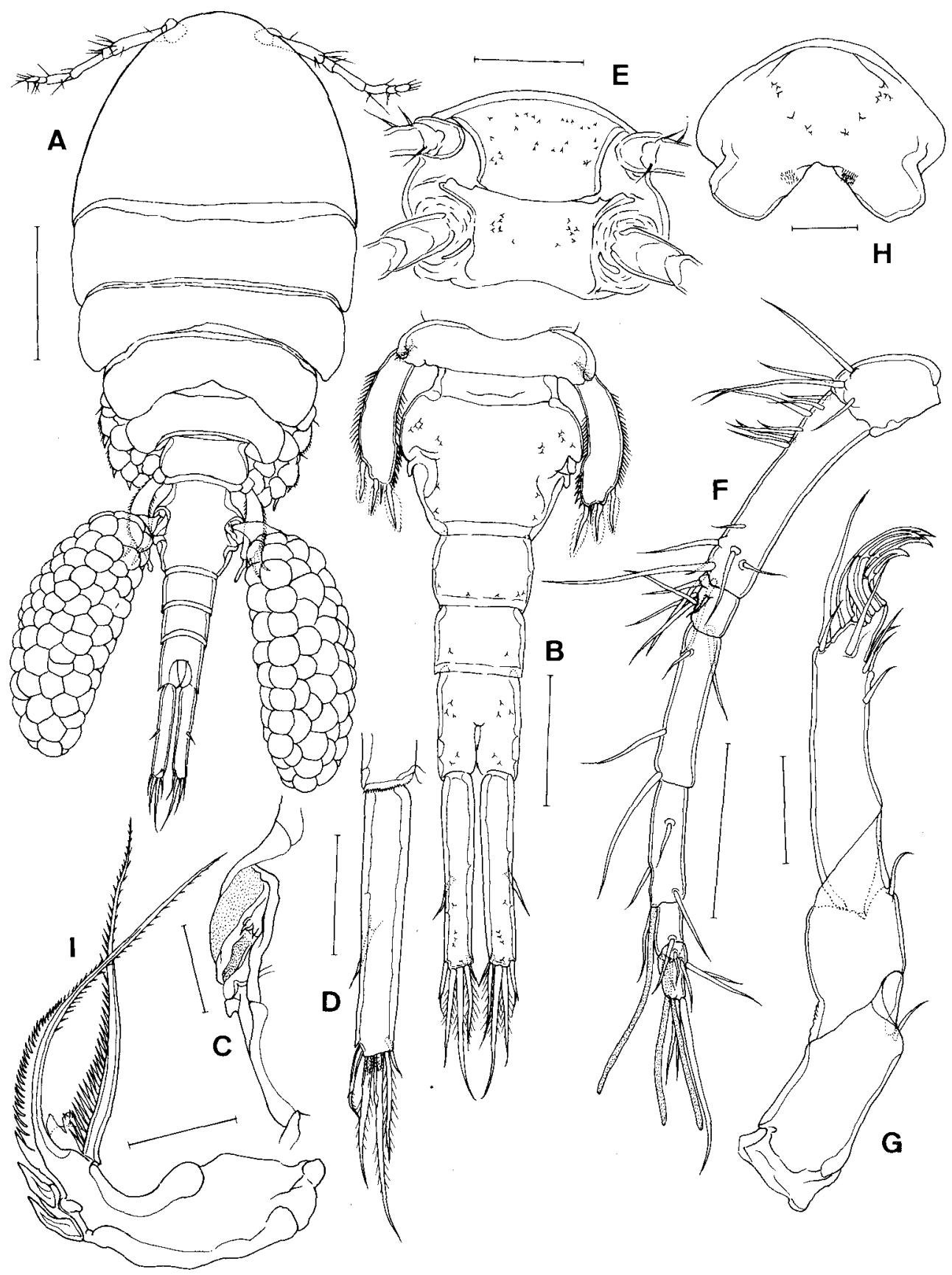

Fig. 7. Anthessius mytilicolus Reddiah, 1966, female: A. habitus, dorsal; B. urosome, ventral; C. genital area, dorsal; D. caudal ramus, ventral; E. rostral area, ventral; F. antennule, dorsal; G. antenna; $\mathrm{H}$. labrum, ventral; I. mandible. Scale bars: $0.3 \mathrm{~mm}$ in $\mathrm{A} ; 0.15 \mathrm{~mm}$ in $\mathrm{B} ; 0.05 \mathrm{~mm}$ in $\mathrm{C}, \mathrm{G}, \mathrm{H} ; 0.1$ $\mathrm{mm}$ in $\mathrm{D}, \mathrm{E}, \mathrm{F} ; 0.03 \mathrm{~mm}$ in $\mathrm{I}$.

of armature: $4,15,6,3,4+1$ aesthete, $2+$ laesthete, and $7+1$ aesthete; all setae naked. Antenna (Fig. 7G) 3-segmented, with formula of armature: 1, 1 and $7+$ IV. 

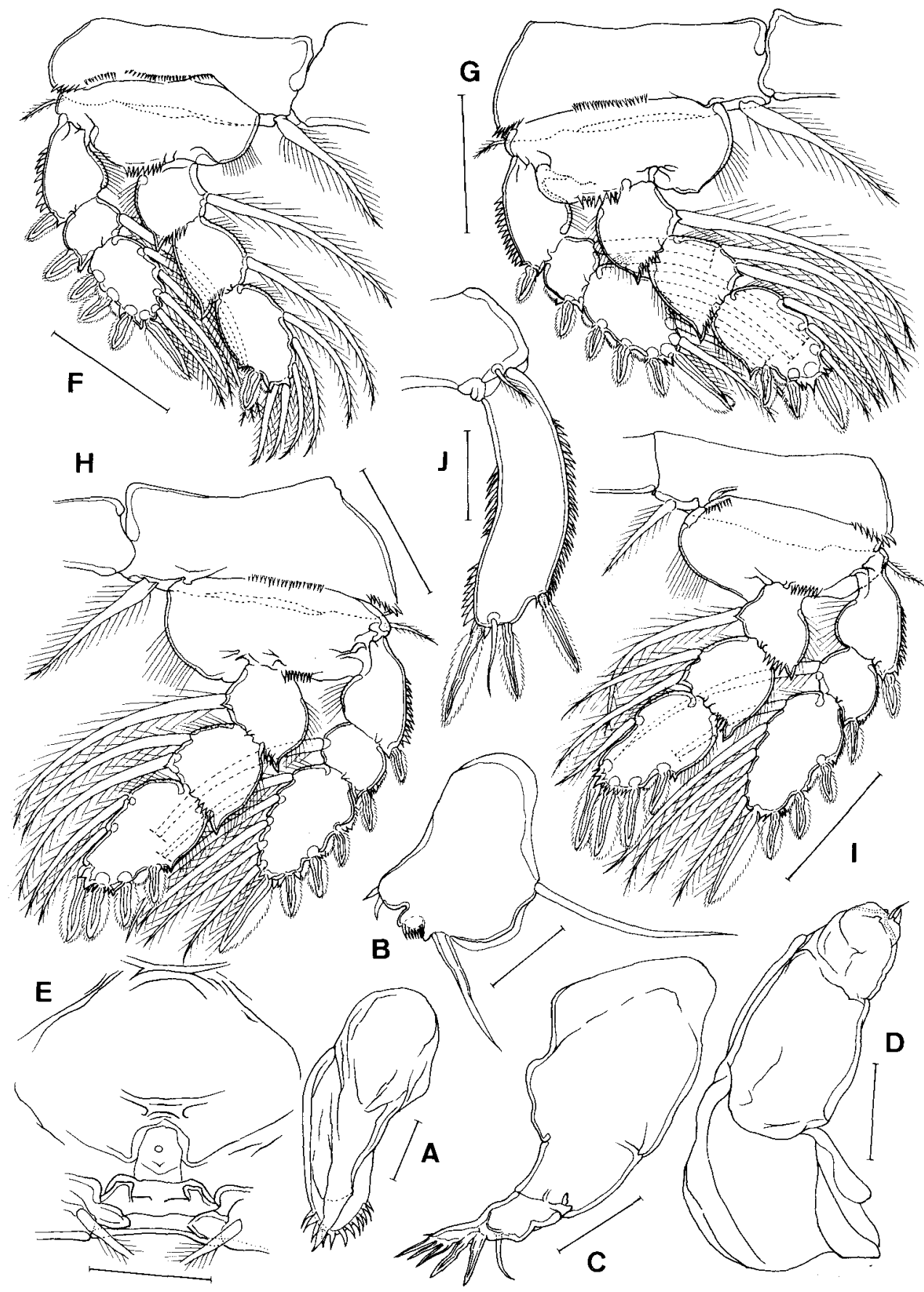

Fig. 8. Anthessius mytilicolus Reddiah, 1966, female: A. paragnath; B. maxillule; C. maxilla; D. maxilliped; E. area between maxilliped and intercoxal plate of leg 1; F. leg 1, anterior; G. leg 2, anterior; H. leg 3, anterior; I. leg 4, anterior; J. leg 5, dorsal. Scale bars: $0.01 \mathrm{~mm}$ in A; $0.02 \mathrm{~mm}$ in $\mathrm{B} ; 0.04 \mathrm{~mm}$ in $\mathrm{C} ; 0.03 \mathrm{~mm}$ in $\mathrm{D} ; 0.1 \mathrm{~mm}$ in $\mathrm{E}, \mathrm{F}, \mathrm{G}, \mathrm{H}, \mathrm{I} ; 0.05 \mathrm{~mm}$ in J.

Terminal 4 claws strongly recurved. Labrum (Fig. 7H) broad, posteroventral lobe truncated 


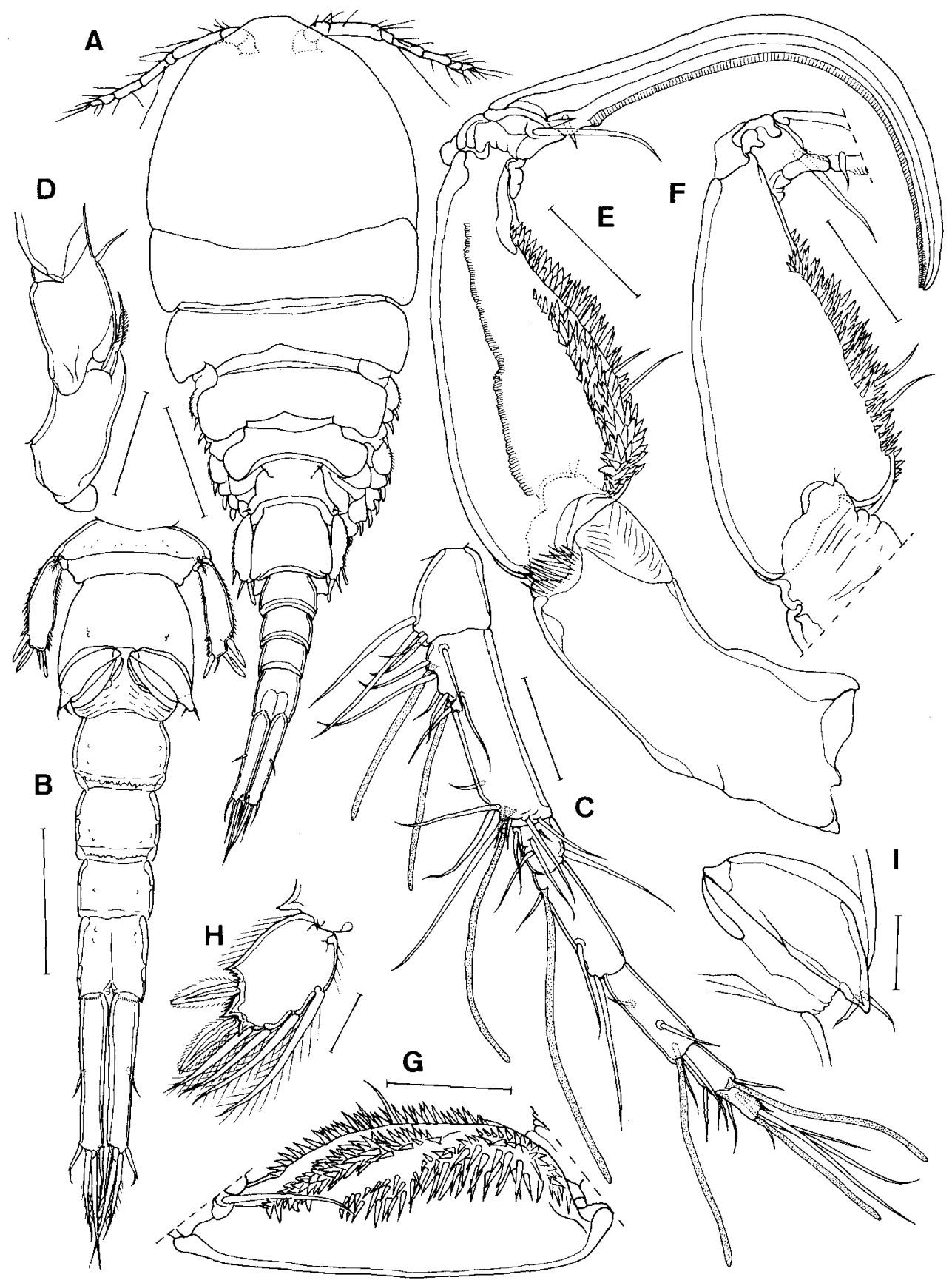

Fig. 9. Anthessius mytilicolus Reddiah, 1966, male: A. habitus, dorsal; B. urosome, ventral; C. antennule, dorsal; D. basal portion of antenna; E. maxilliped, anterior; F. second and third segments of maxilliped, posterior; G. second segment of maxilliped, medial; H. third segment of leg 1 endopod, anterior; I. leg 6, ventral. Scale bars: $0.2 \mathrm{~mm}$ in $\mathrm{A} ; 0.15 \mathrm{~mm}$ in B; $0.05 \mathrm{~mm}$ in C, D, E, F, G; $0.03 \mathrm{~mm}$ in $\mathrm{H}, \mathrm{I}$. 
distally and bearing patch of spinules at medial base. Mandible (Fig. 7I) typical of Anthessius with setiform terminal extension carrying 2 basal outer spines and 1 long inner seta, with a hyaline membranous lamella between these two elements. Paragnath (Fig. 8A) elongate and tipped with denticles. Maxillule (Fig. 8B) with 2 long terminal setae and 2 small lobes, one bearing spinules and other tipped with 2 short setae. Maxilla (Fig. 8C) 2-segmented, first segment large and unarmed; second segment with small proximal seta, larger anterior seta, and 5 smooth, distal spines. Maxilliped (Fig. 8D) 3-segmented, first two segments unarmed, third segment tipped with small spiniform process and 1 small seta. Ventral surface between maxillipeds and first pair of legs (Fig. 8E) not protuberant and smooth.

Legs 1-4 (Figs. 8F, G, H, I) biramous with 3-segmented rami. Armature of legs as follows (Roman numerals indicating spines, Arabic numerals representing setae):

$\begin{array}{lllll}\text { Leg } & \text { Coxa } & \text { Basis } & \text { Exopod } & \text { Endopod } \\ 1 & 0-1 & 1-0 & \text { I-0; I-1; III,I,4 } & 0-1 ; 0-1 ; \text { I,5 } \\ 2 & 0-1 & 1-0 & \text { I-0; I-1; III,I,5 } & 0-1 ; 0-2 ; \text { III,3 } \\ 3 & 0-1 & 1-0 & \text { I-0; I-1; III,I,5 } & 0-1 ; 0-2 ; \text { IV,2 } \\ 4 & 0-1 & 1-0 & \text { I-0; I-1; III,I,5 } & 0-1 ; 0-2 ; \text { IV,1 }\end{array}$

Anterior surface of coxa and basis on all legs with row of marginal spinules and medial margin of basis with row of long hairs. Outer surface of exopod on all legs with marginal row of spinules but that of endopod with row of hairs.

Leg 5 (Fig. 8J) with elongate free segment 3.75 times longer than wide; row of spinules on both lateral and medial surface; terminal elements consisting of 3 spines and 1 naked seta. Leg 6 represented by 2 minute setae located in egg sac attachment area (Fig. 7C).

Male

Body (Fig. 9A) measuring $1,434(1,323-1,581) \mu \mathrm{m}$ long (not including setae on caudal rami) and 454 (422-483) $\mu \mathrm{m}$ wide. Urosome (Fig. 9B) 6-segmented; caudal ramus 5.7 times longer than wide. Antennule as in female except for addition of 3 aesthetes on second segment and 1 aesthete on fourth segment (Fig. 9C). Antenna essentially as in female, except for bearing a spiniform element on basal segment (Fig. 9D). Maxilliped (Fig. 9E) 4-segmented; first segment elongate and unarmed; second segment robust and bearing 3 groups of spines (Fig. 9G), 2 medial setae and a row of corrugated membrane on anterior surface (Fig. 9E); third segment smallest, carrying 2 unequal setae (Fig. 9F); terminal segment drawn out into a long, curved claw bearing a corrugated membrane along medial margin and a small proximal seta. Third segment of first endopod (Fig. 9H) armed with 2 spines and 4 setae. Leg 6 (Fig. 9I) represented by a pointed posteroventral flap on genital somite bearing 2 small, subterminal setae.

Remarks

Anthessius mytilicolus seems to be a host specific poecilostome copepod with wide distribution. So far, it is reported only from the green mussel, Perna viridis, found in Asia. It was first recorded by Reddiah (1966) from the Ennore Estuary in the vicinity of Madras, India, and subsequently by Humes \& Lee (1985) from Hong Kong and Yusookuh (1991) from the Gulf of Thailand. The present report extends the northern limit of this species from Hong Kong to Taiwan. Thus, a full description is given for showing possible geographical variations in morphology.

Upon the discovery of $A$. mytilicolus at Hong Kong, Humes \& Lee (1985) reexamined 
the type specimens of this species deposited in the Zoological Survey of India and made an excellent redescription based on the specimens obtained from Hong Kong. Comparison of A. mytilicolus from Taiwan with Humes \& Lee's (1985) redescription (where Fig. 1 and Fig. 3 were reversed) shows that there are some discrepancies in the male; such as possession of 3 (instead of 2) aesthetes on the second segment of antennule, carrying setiform element on the proximal segment of antenna (see Fig. 9D), and bearing a membranous medial fringe on the claw (see Fig. 9E). However, we consider these discrepancies to be the result of geographical variations.

\section{Occurrence of Symbiotic Hydrozoa}

During the course of our examination for the parasitic copepods of the oyster, Crassostrea gigas, cultured in Taiwan, the polypoid stage of a species of symbiotic hydrozoan, Eugymnanthea japonica Kubota, was encountered. This species of hydrozoan was discovered first by Kubota (1979) from the bivalves in central Japan (Shimoda) and later from the bivalves in southern Japan (Okinawa) near Taiwan (Kubota, 1979, 1987, 1991). The present discovery extends its southern limit to central part of Taiwan-Bu-Dai.

In Taiwan E. japonica was observed throughout the year in the washings of the oysters from $\mathrm{Bu}-\mathrm{Dai}$ area and never found in those obtained from Wang-Gong area, which is about $80 \mathrm{~km}$ north to Bu-Dai. The hydrozoans were found attached to the mantle of the host, but, just like the attachment of those parasitic copepods, they were easily dislodged from their attachment by gently shaking the opened oysters in sea water.

Although two other species of bivalves, the circular clam, Cyclina sinensis, and the hard clam; Meretrix lusoria, both obtained from Bu-Dai area were regularly examined in our year-long survey for parasitic copepods, hydrozoans were not recovered from them.

\section{Acknowledgements}

We would like to acknowledge with thanks Ms. Yu-Fen Pai, Ms. Chia-Ling Hwang and Ms. Hsiau-Wen Yang for their assistance in the examination of the bivalve mollusks for copepod parasites. Dr. Shin Kubota of Seto Marine Biological Laboratory, Kyoto University kindly identified for us the symbiotic hydrozoans from the oysters and placed in our disposal the specimens of Anthessius mytilicolus that he recovered from the green mussels collected from Bu-Dai, Taiwan. This study was made possible through a grant (NSC 87-2313-13-021-012) from the National Science Council of Taiwan to Ching-Long Lin and another grant from the Paramitas Foundation of U.S.A. to Ju-Shey Ho.

\section{References}

Ho, J.-S. 1996. Myicolid copepods and mass mortality of cultured hard clams (Meretrix). Phuket Mar. Biol. Ctr. Spe. Publ., No. 16, pp. 61-70.

Ho, J.-S. \& Kim, I.-H. 1991. Copepod parasites of commerical bivalves in Korea. II. Copepods from cultured bivalves. Bull. Korean Fish. Soc., 24: 369-396.

Ho, J.-S. \& Kim, I.-H. 1992. A new genus of poecilostome copepod of the family Myicolidae parasitic in a commercial clam from Malaysia. J. Nat. Hist., 26: 303-309.

Ho, J.-S. \& Yoosukh, W. 1994. Ostrincola humesi sp. nov., a myicolid copepod(Poecilostomatoida) parasitic in rock oysters cultured in the Gulf of Thailand. Hydrobiol., 288: 151-155.

Humes, A. G. 1986. Myicola metisiensis (Copepoda: Poecilostomatoida), a parasite of the bivalve Mya arenaria in eastern Canada, redefinition of the Myicolidae, and diagnosis of the Anthessiidae $n$. fam. Can. J. Zool., 64: 1021-1033.

Humes, A. G. \& Gooding, R. U. 1964. A method for studying the external anatomy of copepods. Crustaceana, 6(3): 238-240. 
Humes, A. G. \& Lee, S. Y. 1985. The poecilostome copepod Anthessius mytilicolus Reddiah, 1966, associated with the mussel, Perna viridis (L.) at Hong Kong. Asian Mar. Biol., 2: 85-92.

Kim, I.-H. 1997. Two new species of poecilostomatoid copepods associated with the bivalve Dosinella penicillata in the Yellow Sea. Korean J. Biol. Sci., 1: 15-23.

Kubota, S. 1979. Occurrence of a commensal hydroid Eugymnanthea inquilina Palombi from Japan. J. Fac. Sci. Hokkaido Univ. Ser. VI, Zool., 21(4): 396-406.

Kubota, S. 1987. Occurrence of a bivalve-inhabiting hydroid Eugymnanthea inquilina japonica Kubota from Okinawa Island, southwest of Japan, with notes on parthenogenesis. Galaxea, 6:31-34.

Kubota, S. 1991. The stability of diagnostic characters of the medusa of bivalve-inhabiting hydrozoan Eugymnanthea japonica Kubota in Japan. Proc. Japan. Soc. Syst. Zool., 44:1-7.

Reddian, K. 1966. Copepods associated with Indian molluscs-[E]. Anthessius mytilicolus n. sp. from Mytilus viridis at Ennore. J. Mar. Biol. Assoc. India, 8: 290-294.

Tanaka, O. 1961. On copepods associated with marine pelecypods in Kyushu. J. Fac.Agr., Kyushu Univ., 11: 249-273.

Yoosukuh, W. 1991. Poecilostome copepods symbiotic with cultured bivalve molluscs in the Gulf of Thailand. Proc. 4th Internatl. Conf. Copepoda, Bull. Plank. Soc. Japan, Spec. Vol., pp. 637-641. 